\title{
SMEs Managers - A Need for Competence
}

\author{
Katarzyna Szczepańska-Woszczyna*
}

\begin{abstract}
The issue of managerial competencies is important due to the fact that it is the management staff who are responsible for developing a corporate strategy, especially as far as SMEs are concerned. A process of competence development in SMEs is worth being investigated as it proceeds differently than in big organizations, the experience of which is used in the presented research. SMEs are the driving force of economy in well developed countries. Their competitiveness is largely determined by their managers' competencies. They are inextricably linked with the process of education. Education systems and school curricula equip young people with knowledge and skills that are the basis for the later development of professional competencies and the ability to learn throughout one's life. They are complemented by the process of lifelong learning, various forms of non-formal education and self-education. On the other hand, knowledge of competencies necessary for a given position (in this case managerial) is a source of knowledge for the development of an educational process fulfilling the needs of the labour market. The presented study covers the findings of a test survey, purpose of which was to identify the importance of key managerial competencies, competencies needed by managers in SMEs, and to define a set of competencies that managers wish to develop.
\end{abstract}

Key words: manager, competence, managerial competencies, small and medium-sized enterprises (SME), educational model.

\section{Introduction}

The issue of managerial competences is particularly important due to the fact that it is the management staff which is responsible for developing corporate strategy. A manager is a person responsible for implementation of the managerial process, especially for planning and decision making, organizing, leading people and controlling human, financial, material and information resources. He/she is the head of the team (people, organization, organizational unit) and their role is to make the team to achieve the established goals in the

\footnotetext{
* Katarzyna Szczepańska-Woszczyna, The Academy of Business in Dąbrowa Górnicza, Dąbrowa Górnicza, Poland; kszczepanska@wsb.edu.pl
} 
context of the changing market. The management staff forms a heterogeneous group. Various classifications show the elements differentiating the status of individual managers in organizations.

Studies on competencies must be linked with studies on the process of education. In the Polish educational system, the authoritarian model of education and upbringing has dominated. A graduate educated in this model is properly prepared only for the fulfilment of orders. The authoritarian model assumes that there is one correct picture of the world, and one way to respond to it (Szałach, 2012). It does not allow creativity. In the subjective model of education; graduates can be creative, independently formulate and practically implement new projects. This model can form the basis for developing managerial competencies demanding independence, creativity and invention.

Studies on competencies are conducted primarily in large organizations. Several studies carried out in SMEs confirm the link and the impact of competence development on their competitiveness. However, the researchers argue that it is necessary to look at the competence development in SMEs differently than in large organizations, as the form and conditions are different. SMEs play a key role in shaping the economy. They prevail in the economies of developed countries where the economic development largely depends on their conditions. They are not only a source of economic growth, but mean innovation in all spheres of industry, too. They offer jobs for the citizens of the countries concerned. They also offset the negative economic trends and support the restructuring of industry. A sustainable development of the sector is vital to the economy and is a necessary condition to achieve economic growth for several reasons. Firstly, six out of ten workplaces are created by small and mediumsized enterprises. Secondly, SMEs support industry transformation from traditional forms of production to advanced technologies. Thirdly, SMEs play a significant role in the development of innovations with the aim to increase their own competitiveness. Organizations in this sector also contribute to the development of the global market. Innovation plays a key role in building the competitiveness of SMEs, which is conditioned by competence, especially the competencies of the management staff.

An interest in the issues of the development of individual and organizational competencies is increasing. It has emerged as a consequence of the continuous search for sources of performance and improving the performance of employees, including those at managerial positions. Since McClleland and Boyatzis defined the assumptions of the concept of competencies, their importance, as of a factor of success and a source of competitive advantage of the organization is still growing and is of interest to both the theory and practice of management. Boyatzis (1982) defines the notion of competence broadly, as an essential, fundamental characteristic that results in effective and/or better fulfilment of professional duties. In his opinion, professional competencies represent potentials and capabilities (to do something). The individual's set of 
competencies reflects his/her abilities - competencies are identified by the characteristics of a manager who does his/her job really well. These include his/her motivation, personal qualities, skills, self-representation, social roles, knowledge, etc. Hoffman (1999) highlights the fact that the meaning of "competence" depends on the purpose of using it. He distinguishes two meanings of the term: 1) relating to the results, the effects of actions; it is a satisfactory performance of assigned tasks - competence as an observable performance, 2) relating to the essential characteristics, attributes required of a person to achieve satisfactory results - competence as an attribute of a person. In addition to knowledge, skills, specific standards of behaviour and components of competence, Spencer (1993) lists ethical values and enthusiasm, depending on an individual's predispositions that are extremely difficult to learn, yet, according to the author, critical for performing tasks. Before the term "competence" had been introduced, terms such as abilities, skills, predispositions, qualifications, and work potential were used in literature. Currently, these terms are considered the basic elements of competence. For example, Lévy-Leboyer (1997) believes that competencies refer to an integrated use of abilities, personality traits, as well as knowledge and skills to complete a task successfully). According to Rakowska and Sitko-Lutek (2000) and Filipowicz (2004), competence can be defined by three components: knowledge, skills and attitudes. Rostowski's (2008) definition includes the following elements: talents, skills, abilities, knowledge, physical skills, style, personality, principles, values, and interests. According to Walczak (2009), competencies include: knowledge (explicit and implicit), skills, abilities, the system of values and personality traits. Oleksyn (2010) and Pocztowski (2003) pay attention to the fact that contemporary understanding of managerial competencies is very broad and is close (and even tantamount) to the concept of human capital. This understanding of competence includes: talents, predispositions, interests and internal motivation (Oleksyn considers them the most important components of competence); education and knowledge (inter-related), which are not of such an importance as it is generally thought (due to the varying quality of education), professional experience and practical skills, based on both the years of work and the amount and variety of professional experiences, as well as attitudes, behaviour, characteristic features, psycho-physical condition, the formal right to act on behalf of the organization, powers of attorney given and health.

The concept of managerial competency (and competencies) can be contrasted with the job-related concepts of competence (and competencies). Woodruffe (1991) distinguishes the areas of competence, related to functions of the job that an individual can perform, from competency, referring to a person's behaviour underpinning his/her competent performance. A holistic model of professional competence has been developed by Cheetham and Chivers $(1996,1998)$ comprising five sets of inter-connected competency and competencies. A modified version of the Cheetham and Chivers model, distinguishing cognitive 
and functional competencies, personal (and ethical) competencies, and overarching meta-competencies, has been used to predict future management skill needs (Winterton et al., 2000). These four dimensions provide a convenient framework within which the competencies of SME managers, that must be developed, can be considered: tacit/practical knowledge linked with, for instance, specific functional competences; technical/theoretical knowledge representing the underlying principles and theories of the managerial profession; procedural knowledge; contextual knowledge, background knowledge that is specific for the organization and the sector in which a manager operates.

The need for competence in SMEs may seem difficult to define due to the diversity of their activities and conditions. There are, however, attempts to define and describe them in the form of models, which are the starting point for the further development of competence. A research conducted by J. Carr (Carr, 1999) shows that the area of common training needs of SMEs is broadly defined by the management. People starting their business activity usually know well their product, technology, and the sector they want to operate in, but they lack knowledge of management, which has not been their domain so far. The competencies needed for SMEs also include those that are not directly related to the product and technical knowledge. Replies of the respondents in the study showed the emerging common needs for the following areas: finance, marketing and sales, human resource management, export, information technology, and strategy/planning. M. Wawrzeńczyk-Kulik (2010) quotes competencies of a small business entrepreneur developed by an international team as a part of the Leonardo da Vinci project. The research carried out within the project, based on psychometric and statistical analysis, helped to distinguish eight general and seven specific competencies, essential for managers of small and medium-sized enterprises. The defined general competencies include: innovation, planning, cooperation, leadership, decision making, self-confidence, perseverance and problem solving. Special competences include: knowledge of the staff; of the assessment and incentive systems; knowledge of recruitment and human resource management; knowledge of advertising and marketing; knowledge of the market; knowledge of production and logistics and knowledge of finance and law. The core competence of managers, which is one of the basic conditions for the development of the SME sector, is the managers' ability to obtain information and to share it with the employees. According to a research conducted by T. Copp (2011), managers associate competences with: interpersonal competences, interpersonal intelligence, interpersonal skills (motivating), knowledge, experience, expertise, reliability, openness, and communication skills. For managers, the most important competencies in business management are: leadership skills (75\%), objectives and activity management $(67.85 \%)$, human resources management $(67.85 \%)$, expertise (46.42\%), objectivity (25\%), self-control (17.85\%). M. Lis (2012) highlights the importance of competences related to quality management. As an example, we 
can mention the model used in companies implementing integrated systems using WCM - World Class Manufacturing methods. This innovative approach to management aims to combine the best practices in the sphere of production, i.e. the process of the improvement and innovation of everyday activities.

\section{Methodology and research methods}

The aim of the research was to identify the employers' expectations from the recruited management staff and the employees, as for their knowledge, skills, attitudes and behaviour. Based on the theory of managerial competencies, the goal of the study and the intention of the research was to answers to the following questions:

What kind of knowledge, combined with skills and competencies, do managers employed in SMEs have? To what extent are they useful in their work? What do the employers expect from the managers and how do they assess their ability and willingness to perform their professional duties? What does results from the comparison of the model of education and signals from the labour market?

The research was conducted by means of a direct survey. The instrument of data collection was a questionnaire. The questionnaire consisted of 15 questions with a mixture of Likert-scale, multiple choice and closed-ended questions. The questionnaire was divided into three sections: the expectations of employers from the management staff in terms of knowledge, skills, qualities and attitudes; the managers' education and demographic data.

200 employers (owners, managers, their agents or employees responsible for the personnel policy of companies in Silesia Region (Poland)) took part in the research. We excluded the respondents who failed to answer at least 20 per cent of the questions. A total number of 180 usable questionnaires was received. The survey was anonymous. Most of the represented companies operated in the private sector $(75 \%)$, the remaining $25 \%$, in the state sector. The companies surveyed had their headquarters in cities of all sizes, including more than $40 \%$ of cities with a population over 100 thousand residents. The enterprises were of different sizes (employment criterion): micro-enterprises accounted for $55.3 \%$ of the respondents, small ones - over $25.5 \%$ of respondents and the medium sized ones $-19.3 \%$. The highest number of respondents was from the field of business (20.6\%), then manufacturing (10.2\%), public administration (10.0\%), construction (8.9\%), financial intermediation $(6.1 \%)$; transportation, warehouse management, communication (5.6\%) and others followed. The respondents completed education as follows: higher education (67.2\%): economic education $-19.8 \%$, managerial or technical education $-16.5 \%$, and higher education in the field of humanities $-13.2 \%$; secondary education $(16.1 \%)$ : economic education $13.8 \%$ and technical education - $13.8 \%$; post-secondary education $(10.0 \%)$ : economic education $-38.9 \%$, technical education $-16.7 \%$. 
The survey was sample-based. Non-random sampling was applied, advantages and disadvantages specific to this method of sampling were considered (Steczkowski, 1995). A small group of those surveyed does not authorize to make generalizations, but allows the identification of specific mechanisms, formulation of questions and of conclusions. Tested on a larger sample, the formulation of more certain, useful theses on a larger scale would be possible. The data were collected in July and September 2012.

Contingency tables were used to analyse the gathered data. Counted values of the relationship measures were merely supplement to the interpretation of the content of contingency tables. The chi-square test, Cramer's V coefficient and Lambda $\Lambda$ were used to analyse the measures of the relationship strength between the variables. Data analysis was accomplished using IBM SPSS Statistics 20.

\section{Findings}

While recruiting new employees for managerial positions, employers take into account the criteria that characterize the candidates as for their suitability (usefulness) and for the expected professional roles. The assessment was based on 14 evaluation criteria. The data obtained indicate that experience of the hired managers is very important- it is taken into account by $58.3 \%$ of employers. Almost half of the respondents chose the following criteria: a degree in a specific field of study (50.6\%), knowledge of foreign languages - $46.1 \%$, personality traits and character ("good impression"). The employers are willing to employ those applicants who have sufficient qualification and certificates from additional courses, training, etc. (28.9\%) and who, before they start working, have done internships and have taken placements (25.0\%). Only 3.9\% of the respondents are ready to hire people without professional experience for a managerial position. According to these employers, employees with no previous work experience do not bring negative behaviour, habits and experiences and they have lower salary demands. The criteria which employers take into account the least are the demographic criteria. The family situation of the candidate and his/her place of residence are taken into consideration by $2.8 \%$ of the respondents, gender by $3.9 \%$ and the age by $8.9 \%$ of respondents.

As the size of the company was expected to be an important factor, various attitudes of the employers, their views on the recruitment criteria were compared (different things are expected from a small company employee and the specific character of a large organization may affect other employer' requirements). In all three groups, the most important recruitment criterion was the applicants' professional experience (53.9 - 64.5\% of the responses). Personal qualities of the applicants were considered important as well. In small and medium-sized companies, a candidate's qualification is important. In companies employing many people, job positions become specialized, so it is important to adjust 
education, while in micro-companies one person often performs a wide variety of activities adapting to the specific character of the company, so willingness to learn and adaptability are more important than the particular field of completed study. In medium-sized enterprises, qualification in a particular field an additional courses, training, etc. are important, as indicated by almost one half of the responses. This means that medium-sized companies prefer managers prepared for the job by external institutions. In micro-companies, neither a higher education diploma, computer skills, nor the type of higher education are of such an importance as it is in the case of bigger companies. In the smallest companies, recommendations from third parties are decisive. This group of employers, unlike in bigger companies, would considers hiring managers with no previous work experience (6.7\% of the responses). Detailed data are presented in Table 1.

\begin{tabular}{|c|c|c|c|c|c|}
\hline \multirow[b]{2}{*}{ Criterion } & \multirow{2}{*}{ 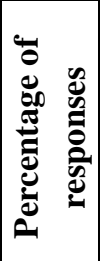 } & \multirow{2}{*}{ 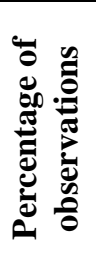 } & \multicolumn{3}{|c|}{$\begin{array}{l}\text { Company size (by } \\
\text { number of } \\
\text { employees) (in \%) }\end{array}$} \\
\hline & & & $\begin{array}{l}\hat{\theta} \\
\stackrel{0}{\circ} \\
\hat{\sigma}\end{array}$ & 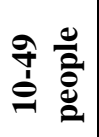 & 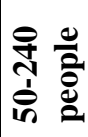 \\
\hline Professional experience & 15.6 & 58.3 & 53.9 & 63.4 & 64.5 \\
\hline Field of study & 13.5 & 50.6 & 37.1 & 68.3 & 51.6 \\
\hline Language skills & 12.3 & 46.1 & 50.6 & 43.9 & 38.7 \\
\hline $\begin{array}{l}\text { Traits of personality and character ("'good } \\
\text { impression") }\end{array}$ & 11.7 & 43.9 & 39.3 & 46.3 & 54.8 \\
\hline $\begin{array}{l}\text { Qualifications confirmed with the certificate and } \\
\text { certificates of completing the additional course }\end{array}$ & 7.7 & 28.9 & 27.0 & 24.4 & 48.4 \\
\hline Internship or placement & 6.7 & 25.0 & 23.6 & 26.8 & 19.4 \\
\hline $\begin{array}{l}\text { Higher education diploma (without specifying a field } \\
\text { of study) }\end{array}$ & 4.6 & 17.2 & 11.2 & 19.5 & 29.0 \\
\hline $\begin{array}{l}\text { Results of a competence test or other, professional } \\
\text { examinations }\end{array}$ & 4.6 & 17.2 & 21.3 & 12.2 & 9.7 \\
\hline Computer skills & 4.0 & 15.0 & 6.7 & 22.0 & 29.0 \\
\hline Recommendations by other people & 3.6 & 13.3 & 18.0 & 7.3 & 12.9 \\
\hline Type of university (public/non-public) & 2.8 & 10.6 & 5.6 & 12.2 & 16.1 \\
\hline Experience gained abroad & 1.5 & 5.6 & 5.6 & 4.9 & 6.5 \\
\hline $\begin{array}{l}\text { No professional experience (the company will prepare } \\
\text { to work best) }\end{array}$ & 1.0 & 3.9 & 6.7 & 2.4 & 0.0 \\
\hline Family situation, place of residence & 0.7 & 2.8 & 1.1 & 4.9 & 3.2 \\
\hline Total & $\begin{array}{r}100 . \\
0\end{array}$ & $\begin{array}{r}375 . \\
0\end{array}$ & & & \\
\hline
\end{tabular}

Tab. 1 The main criteria taken into consideration by employers hiring managers (multiple answers) by company size (number of employees) 


\section{Acta Technologica Dubnicae \\ volume 4, 2014, issue 1}

Another group of ratings is related to the candidates' skills and qualities for managerial positions. Almost one half of the respondents appreciates applicants' willingness to improve qualifications and their focus on development. One in three employers considers the candidates' general intelligence (erudition, reaction), creativity (the perceived "individuality" in conversation and behaviour), communication skills, knowledge about the industry, about the market the company operates in, as well as certificates, to be important. The ranking by employers in this group of criteria is presented in Table 2 .

\begin{tabular}{|c|c|c|c|c|c|c|}
\hline Criterion & 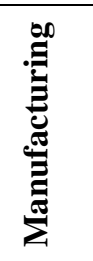 & 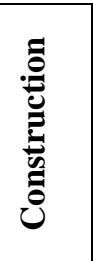 & $\underset{\mathbb{F}}{\mathbb{E}}$ & 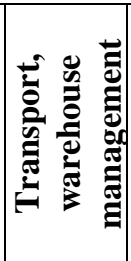 & 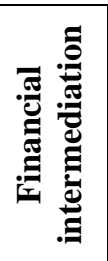 & 兽 \\
\hline Knowledge confirmed with certificates & 22.7 & 12.5 & 24.3 & 20.0 & 27.3 & 66.7 \\
\hline $\begin{array}{l}\text { Willingness to improve qualifications, } \\
\text { focus on development }\end{array}$ & 31.8 & 43.8 & 45.9 & 30.0 & 36.4 & 55.6 \\
\hline Professional experience & 72.7 & 56.2 & 59.5 & 70.0 & 54.5 & 50.0 \\
\hline Availability & 4.5 & 37.5 & 24.3 & 20.0 & 0.0 & 22.2 \\
\hline Creativity & 40.9 & 31.2 & 45.9 & 40.0 & 36.4 & 44.4 \\
\hline $\begin{array}{l}\text { Qualifications not confirmed with } \\
\text { certificates }\end{array}$ & 22.7 & 0.0 & 2.7 & 0.0 & 0.0 & 5.6 \\
\hline Age & 13.6 & 12.5 & 8.1 & 0.0 & 0.0 & 11.1 \\
\hline $\begin{array}{l}\text { General intelligence (erudition, } \\
\text { reactions) }\end{array}$ & 63.6 & 37.5 & 29.7 & 60.0 & 9.1 & 33.3 \\
\hline Gender & 4.5 & 0.0 & 8.1 & 0.0 & 0.0 & 0.0 \\
\hline Defined specialist professional skills & 31.8 & 50.0 & 27.0 & 0.0 & 45.5 & 38.9 \\
\hline Interests, hobbies & 4.5 & 0.0 & 2.7 & 0.0 & 0.0 & 0.0 \\
\hline $\begin{array}{l}\text { Knowledge of the industry, market, } \\
\text { company activities }\end{array}$ & 45.5 & 18.8 & 40.5 & 30.0 & 54.5 & 27.8 \\
\hline Knowledge of law & 0.0 & 6.2 & 5.4 & 0.0 & 18.2 & 11.1 \\
\hline Presentation skills & 0.0 & 12.5 & 16.2 & 10.0 & 9.1 & 11.1 \\
\hline Cultural behaviour & 4.5 & 37.5 & 16.2 & 0.0 & 27.3 & 11.1 \\
\hline Interpersonal skills & 27.3 & 18.8 & 8.1 & 30.0 & 27.3 & 11.1 \\
\hline Negotiation skills & 13.6 & 43.8 & 10.8 & 10.0 & 9.1 & 0.0 \\
\hline
\end{tabular}

Tab. 2 Key features that determine the recruitment of candidates for managerial positions (multiple answers) by sectors (in \%) 
The structure of competencies consists of, inter alia: theoretical and practical knowledge (general and special), skills (proficiency when using relevant knowledge while performing tasks) and certain characteristics and attitudes, i.e. one's reactions to the environment. Such a structure of competencies was used to identify employers' expectations from the people to be employed or working managers. According to more than $60 \%$ of the respondents, from the point of view of the labour market, usefulness of knowledge, selected skills typical for middle and senior managers and general economic knowledge are important, as well as knowledge of the latest trends in organization and management (approx. $40 \%$ of respondents believed that this knowledge is important and about $13 \%$ of respondents considered it to be unnecessary). The need for general knowledge in humanities was ranked the lowest (17\% of the respondents believe that it is needed, almost one in two thinks quite the opposite). When the ambition of being an entrepreneur or a manager, one's access to sources of knowledge is much better, but at the same time, one has to face a number of specific barriers related to the environment (Szczepańska-Woszczyna and Dacko-Pikiewicz, 2007, Dacko-Pikiewicz, 2008, Kurowska-Pysz, 2012). According to the respondents, it is not only important to possess knowledge, but above all, it is essential to be able to apply it into practice. For more than $70 \%$ of the respondents, the capacity to solve problems and to make decisions was decisive, computing skills, using email and the Internet were of a high importance for almost $90 \%$ of the respondents. Almost $80 \%$ of the respondents believe that interpersonal skills (networking, the ability not to alienate people, empathy) are necessary (only $4 \%$ thinks the opposite), the ability to work in a group (team work) (respectively approx. $75 \%$ and 2\%). Opinions of the representatives of state-owned enterprises were only slightly different from the opinions of the representatives of private companies. Individual respondents' ratings of the components of knowledge and skills were the basis for calculating their average ratings, which are considered an indicator of the desired set of components of knowledge managers must have. Components of knowledge and skills expected by employers are presented in Table 3 . 


\section{Acta Technologica Dubnicae \\ volume 4, 2014, issue 1}

\begin{tabular}{|c|c|c|c|c|c|c|}
\hline Knowledge and skills & $\begin{array}{c}\text { Not } \\
\text { necessary- } \\
1 \\
\end{array}$ & 2 & 3 & 4 & $\begin{array}{c}\text { Very } \\
\text { necessary- } \\
5 \\
\end{array}$ & $\begin{array}{c}\text { Average } \\
\text { rating }\end{array}$ \\
\hline $\begin{array}{l}\text { General economic } \\
\text { knowledge }\end{array}$ & 9.0 & 19.1 & 34.0 & 28.2 & 9.6 & 3.10 \\
\hline $\begin{array}{l}\text { General humanistic } \\
\text { knowledge }\end{array}$ & 23.5 & 29.9 & 28.3 & 14.4 & 3.7 & 2.45 \\
\hline $\begin{array}{l}\text { Knowledge of management } \\
\text { and its application, } \\
\text { knowledge of new trends in } \\
\text { organization and } \\
\text { management }\end{array}$ & 6.5 & 12.9 & 31.2 & 33.3 & 16.1 & 3.40 \\
\hline $\begin{array}{l}\text { Managerial and leadership } \\
\text { skills }\end{array}$ & 6.4 & 9.0 & 24.5 & 34.6 & 25.5 & 3.64 \\
\hline HR management skills & 8.6 & 12.4 & 22.6 & 29.0 & 27.4 & 3.54 \\
\hline $\begin{array}{l}\text { Skills of financial analysis } \\
\text { and planning }\end{array}$ & 7.4 & 16.5 & 21.8 & 31.4 & 22.9 & 3.46 \\
\hline $\begin{array}{l}\text { Skills of managing financial } \\
\text { and material resources }\end{array}$ & 8.5 & 11.2 & 26.1 & 31.9 & 22.3 & 3.48 \\
\hline $\begin{array}{l}\text { Skills of using marketing } \\
\text { tools, marketing } \\
\text { management }\end{array}$ & 9.0 & 14. & 22.3 & 31.9 & 22.3 & 3.44 \\
\hline $\begin{array}{l}\text { Skills of using financial } \\
\text { accounting instruments }\end{array}$ & 13.4 & 17.7 & 18.8 & 32.8 & 17.2 & 3.23 \\
\hline $\begin{array}{l}\text { Skills of using modern } \\
\text { technology, production } \\
\text { processes }\end{array}$ & 14.0 & 12.4 & 23.7 & 33.9 & 16.1 & 3.26 \\
\hline $\begin{array}{l}\text { Problem solving and } \\
\text { decision-making skills }\end{array}$ & 0.5 & 5.3 & 23.0 & 37.4 & 33.7 & 3.98 \\
\hline $\begin{array}{l}\text { Argumentation and } \\
\text { persuasion skills }\end{array}$ & 1.1 & 7.0 & 22.0 & 34.9 & 34.9 & 3.96 \\
\hline $\begin{array}{l}\text { Skills of transferring and } \\
\text { sharing knowledge }\end{array}$ & 2.7 & 5.9 & 29.6 & 36.0 & 25.8 & 3.76 \\
\hline $\begin{array}{l}\text { Interpersonal skills } \\
\text { (networking, an ability not } \\
\text { to alienate people, empathy }\end{array}$ & 1.1 & 5.9 & 13.9 & 42.2 & 36.9 & 4.08 \\
\hline Team -working skills & 2.1 & 5.9 & 14.9 & 38.8 & 38.3 & 4.05 \\
\hline $\begin{array}{l}\text { Listening and obedience } \\
\text { skills (accepting superiors' } \\
\text { orders) }\end{array}$ & 2.7 & 7.0 & 30.1 & 32.8 & 27.4 & 3.75 \\
\hline $\begin{array}{l}\text { Creative skills (proposing } \\
\text { ideas, changes, observation } \\
\text { of the market and } \\
\text { competitors) }\end{array}$ & 5.3 & 4.8 & 22.3 & 37.2 & 30.2 & 3.82 \\
\hline $\begin{array}{l}\text { Using a computer, email and } \\
\text { the Internet }\end{array}$ & 3.2 & 5.3 & 15.5 & 33.7 & 42.2 & 4.06 \\
\hline Foreign language skills & 8.6 & 11.3 & 30.1 & 25.3 & 24.7 & 3.46 \\
\hline $\begin{array}{l}\text { Taking risk (even at the } \\
\text { expense of unsuccessful } \\
\text { undertakings) }\end{array}$ & 9.1 & 10.8 & 28.5 & 36.0 & 15.6 & 3.38 \\
\hline
\end{tabular}

Tab. 3 Usefulness of knowledge and skills in managers' careers 
The vast majority of employers expect that the candidates for managerial positions have certain characteristics, abilities and behaviours. The characteristics ranked the highest include: responsibility, loyalty to the company and superiors, regularity, reliability, honesty, ethics and truthfulness. As far as these characteristics are concerned, almost all the respondents $(95.0 \%, 90.0 \%$, $87.3 \%$ and $87.8 \%$ ) believe that these represent the qualities a candidate should possess.

The findings of the research indicate that creativity (proposing new ideas, recognizing potential chances, looking for opportunities) is highly valued by $81.6 \%$ of the respondents, $2.3 \%$ of the respondents do not find it necessary. The same applies to independence, activity, initiative ( $78.8 \%$ and $1.7 \%$ respectively), and self-control in stressful situations $(86.6 \%$ and $0.6 \%$ respectively). These qualities indicate the expectations of a creative approach to tasks assigned and promote a more individualistic approach. Many of the required qualities are related to the need to cooperate with other people, so qualities like the capability take joint action (important to $66.2 \%$ of the respondents), friendliness, openness to the problems of others $(62.3 \%)$ are desired. The employers expect subordinates to have a creative approach to tasks, but only within the precisely defined limits, which means that creativity is not a part of the individual's development, but rather a tool used by the employer. Despite the fact tha employers prefer employees who are individualists, this individualism is clearly embedded within the group which defines it. Employers also appreciate such qualities as: innovation, flexibility (availability) and confidence (decisiveness). The qualities which the respondents ranked the lowest included: resigning easily, succumbing to the difficulties, striving for the maximum amount of benefits and competing with the others (taking care of their own interests). Employers are not searching for charismatic leaders, but creative employees, who are, at the same time, responsible and independent, but only within the defined limits. The desired characteristics that a candidate for a managerial position should have are presented in Table 4. 


\begin{tabular}{|l|c|c|c|c|c|c|}
\hline Attitudes and behaviours & $\begin{array}{c}\text { Not } \\
\text { necessary- 1 }\end{array}$ & $\mathbf{2}$ & $\mathbf{3}$ & $\mathbf{4}$ & $\begin{array}{c}\text { Very } \\
\text { necessary- 5 }\end{array}$ & $\begin{array}{c}\text { Average } \\
\text { score }\end{array}$ \\
\hline Assertiveness & 4.8 & 4.8 & 25.1 & 33.2 & 32.1 & $\mathbf{3 . 8 3}$ \\
\hline $\begin{array}{l}\text { Honesty, ethics, } \\
\text { truthfulness }\end{array}$ & 3.7 & 7.0 & 19.8 & 34.8 & 34.8 & $\mathbf{3 . 9 0}$ \\
\hline $\begin{array}{l}\text { Creativity (proposing new } \\
\text { ideas, recognizing } \\
\text { potential chances, looking } \\
\text { for opportunities) }\end{array}$ & 0.5 & 3.7 & 19.1 & 34.6 & 42.0 & $\mathbf{4 . 3 1}$ \\
\hline $\begin{array}{l}\text { Innovation (implementing } \\
\text { ideas, undertaking new } \\
\text { tasks) }\end{array}$ & 1.1 & 4.8 & 19.7 & 44.7 & 29.8 & $\mathbf{3 . 9 7}$ \\
\hline Responsibility & 1.6 & 1.6 & 13.3 & 35.6 & 47.9 & $\mathbf{4 . 2 7}$ \\
\hline $\begin{array}{l}\text { Self-control in stressful } \\
\text { situations }\end{array}$ & 0.5 & 2.1 & 10.6 & 42.9 & 43.9 & $\mathbf{4 . 2 8}$ \\
\hline Confidence (decisiveness) & 0.5 & 1.6 & 14.9 & 43.1 & 39.9 & $\mathbf{4 . 2 0}$ \\
\hline $\begin{array}{l}\text { Loyalty to the company } \\
\text { and superiors }\end{array}$ & 1.1 & 3.2 & 22.3 & 38.8 & 34.6 & $\mathbf{4 . 0 3}$ \\
\hline $\begin{array}{l}\text { Independence, activity, } \\
\text { innitiative }\end{array}$ & 1.1 & 2.1 & 15.5 & 46.5 & 34.8 & $\mathbf{4 . 1 2}$ \\
\hline Regularity, reliability & 1.1 & 1.1 & 20.7 & 42.0 & 35.1 & $\mathbf{4 . 0 9}$ \\
\hline $\begin{array}{l}\text { Professional flexibility, } \\
\text { availability }\end{array}$ & 0.5 & 5.9 & 22.3 & 46.3 & 25.0 & $\mathbf{3 . 8 9}$ \\
\hline Taking joint actions & 1.1 & 6.9 & 32.3 & 38.1 & 21.7 & $\mathbf{3 . 7 2}$ \\
\hline Taking risk & 2.7 & 9.6 & 30.3 & 37.8 & 19.7 & $\mathbf{3 . 6 2}$ \\
\hline Openness to "otherness" & 5.9 & 24.1 & 36.8 & 21.4 & 12.8 & $\mathbf{3 . 1 1}$ \\
\hline $\begin{array}{l}\text { Resigning easily, } \\
\text { succumbing to difficulties }\end{array}$ & 36.5 & 17.5 & 19.6 & 21.2 & 5.3 & $\mathbf{2 . 4 1}$ \\
\hline $\begin{array}{l}\text { Friendliness, openness to } \\
\text { the problems of the others, } \\
\text { kindness }\end{array}$ & 2.1 & 10.2 & 25.1 & 46.5 & 16.0 & $\mathbf{3 . 6 4}$ \\
\hline $\begin{array}{l}\text { Self-investment } \\
\text { (willingness to improve } \\
\text { one's skills) }\end{array}$ & 4.8 & 6.9 & 14.4 & 48.9 & 25.0 & $\mathbf{3 . 8 2}$ \\
\hline $\begin{array}{l}\text { Competing with others } \\
\text { taking care of their own } \\
\text { interests) }\end{array}$ & 9.0 & 16.5 & 25.0 & 32.4 & 17.0 & $\mathbf{3 . 3 2}$ \\
\hline Optimism, joy of life & 2.1 & 9.6 & 27.7 & 39.4 & 21.3 & $\mathbf{3 . 6 8}$ \\
\hline $\begin{array}{l}\text { Striving to achieve } \\
\text { maximum own benefits }\end{array}$ & 7.5 & 31.0 & 14.4 & $\mathbf{3 . 2 7}$ \\
\hline
\end{tabular}

Tab. 4 Usefulness of attitude and behaviour in managers' career

According to the respondents, not only education is important, but also the field of studies a candidate has completed. The employers think that a degree in economics can guarantee success in the labour market. According to the respondents, the graduates from the following fields have the best chance in the labour market: finance and accounting (app. 27.2\%), computer science and econometrics (24.4\%) and economics (1/5 of the responses), and graduates in 
science of commodities have a little chance. The research confirms a decline of interest in management graduates which is noticed in the labour market. Referring the opinions about the chance of employment of candidates for managerial positions, the following relationships can be seen:

- finance and accounting graduates are in the greatest demand by financial intermediation (55\%) and public administration (45\%); employers in all industries see great employment chances for graduates in this field,

- management graduates are perceived as needed in transport, warehouse management (30\% of the responses), public administration (17\%) and in trade $(13.5 \%)$,

- economics graduates are needed in transportation business, trade and construction (25-30\%),

- employers in the manufacturing industry and in trade and construction recognize the importance of marketing (18.2\% and $12-13.5 \%)$,

- banking arouses interest only in financial intermediation (18.2\%),

- computer science and econometrics are highly valued in the construction sector (almost 44\%) and manufacturing (37\%).

\section{Discussion and conclusions}

The findings indicate that experience is very important for businesses that employ people on managerial positions when hiring managers. It is an important element regardless the size of the company, where a manager is going to be employed. Experience is characterised as knowledge and skills revealed in performing tasks and solving problems. One's experience cannot only be measured by the number of years of service as it is not always tantamount to a better performance at work. Career development from lower to higher positions gives the knowledge on how to do a job, what difficulties and problems employees face, which forms of management are effective, how people work in teams, what encourages them to work, and what weakens their motivation. It also gives the knowledge of their own preferences as to the style and type of job. A manager's experience has an impact on the quality of his/her work and his/her components of competence. The gained experience allows him/her to learn new ways of obtaining and applying knowledge in practice, which in turn allows $\mathrm{him} /$ her to acquire new skills, change attitudes and create new behaviours.

The questioned employers look for qualified managers who have completed additional courses and training as well. In companies employing many people, job positions are specialized, so relevant education should be provided to them. It also means that employers mainly count on the candidates' preparedness for their job, while education in the given field should be provided by external institutions. They have no plan of intensive training for managers but they want to have immediate benefits from the work of the employed managers. This confirms the opinion of other authors that in SMEs, there are no training plans 
developed in terms of the direction and the system, they are rather a response to the needs arising from changes in the environment.

From the point of view of the labour market, usefulness of knowledge and skills specific to middle and senior managers, as well as general economic knowledge, knowledge of the latest trends in organization and management are the most important. These findings correspond with the assumptions of J. Carr, who asserts that the area of common training needs of SMEs is broadly defined by their management. SMEs possess knowledge of their products, technologies and the sector they operate in, but they lack knowledge of management.

The following managers' qualities are considered important: responsibility, loyalty to the company and superiors, regularity, reliability, honesty, ethics and truthfulness. The employers expect their subordinates to have a creative approach to tasks, but only within the limits they determine. It means that creativity is not a part of individual development, but rather a tool used by employers. We can assume that employers prefer employees who are individualists, but this individualism is clearly embedded within the group which defines it. These are the characteristics of small organizations where most employees know each other. The manager of a company is a "universal leader", who becomes almost a "member of the organization family", he is not an anonymous "jumper", typical for large corporations. The manager extracts efficiency out of existing resources, especially the human ones, and neutralizes their weaknesses.

In relevant literature, authors mention several dozens of competences, however, it should be noted that it is extremely difficult to isolate a competence and treat it individually as independent, separated from others; competences are interdependent. However, a group of competencies being the basis for the others can be distinguished. Each concept must take into account the diversity of the business world, if it is expected to have a practical application. Creation of new competences is a matter of convention.

\section{References}

BOYZATIS, R. The Competent Manager: A Model for Effective Performance. New York: John Wiley \& Sons, 1982.

CARR, J. The Role of Higher Education in the Effective Delivery of Multimedia Management Training to Small and Medium-Sized Enterprises. Journal of Educational Technology \& Society, 1999, 2(2).

CHEETHAM, G. and CHIVERS, G. Towards a holistic model of professional competence. Journal of European Industrial Training, 20, 1996, 5, pp. 20-30.

CHEETHAM, G. and CHIVERS, G. The reflective (and competent) practitioner: a model of professional competence which seeks to harmonise the reflective 
practitioner and competence-based approaches. Journal of European Industrial Training, 22, 1998, 7, pp. 267-276.

COPP, T. Kompetencje menadżera w przedsiębiorstwie transnarodowym. Działania współczesnych przedsiębiorstw. Determinanty kulturowe, zasobowe $i$ samorzadowe, Prace Naukowe Wyższej Szkoły Bankowej w Gdańsku, Tom 12, Gdańsk,.

DACKO-PIKIEWICZ, Z. Kształcenie ustawiczne. NIESTRÓJ, R. and WÓDZ, J. (eds.) Zarzadzanie marketingiem w szkole wyższej: absolwenci WSB na rynku pracy. Dąbrowa Górnicza: Wydawnictwo Naukowe Wyższej Szkoły Biznesu w Dąbrowie Górniczej, 2008.

FILIPOWICZ, G. Zarządzanie kompetencjami zawodowymi. Warszawa: PWE, 2004.

HOFFMAN, T. The meanings of competency. Journal of European Industrial Training, 1999, Vol. 23 Issue 6, pp. 275-286.

KUROWSKA-PYSZ, J. Rola kadr w procesach innowacyjnych - wnioski z badań. JURASZEK, J. and KUROWSKA, J. (eds.) Innowacyjność akademicka akceleratorem rozwoju nauki i przedsiębiorczości, pr. zbiorowa, Bielsko-Biała: Wydawnictwo Akademii Techniczno-Humanistycznej w Bielsku-Białej, 2012.

LÉVY-LEBOYER, C. Kierowanie kompetencjami. Bilanse doświadczeń zawodowych. Warszawa: Poltext, 1997.

LIS, M. Innowacyjny system zarządzania WCM na przykładzie przedsiębiorstwa produkcyjnego. DAWIDZIUK, S. and LEWANDOWSKI, M. (EDS.) Innowacyjność w zarzadzaniu: jakościa, produkcja, logistyka, personelem i organizacja. Nauka i praktyka. Warszawa: Wyd. Wyższej Szkoły Menedżerskiej w Warszawie, 2012.

OLEKSYN, T. Zarzadzanie kompetencjami teoria i praktyka. Kraków: Oficyna Ekonomiczna, 2010.

POCZTOWSKI, A. Zarządzanie zasobami ludzkimi: strategie, procesy, metody. Warszawa: PWE, 2003.

RAKOWSKA, A. and SITKO-LUTEK, A. Doskonalenie kompetencji menedżerskich. Warszawa: WN PWN, 2000.

ROSTOWSKI, T. Kompetencje a jakość zarządzania zasobami ludzkimi, SAJKIEWICZ, A. (ed.). Jakość zasobów pracy. Kultura, kompetencje, konkurencyjność. Warszawa: Poltext, 2008.

SPENCER, L. and SPENCER, S. Competence at Work: Models for Superior Performance. John Wiley \& Sons, 1993.

STECZKOWSKI, J. Metoda reprezentacyjna $w$ badaniu zjawisk ekonomicznospołecznych. Warszawa-Kraków: PWN, 1995.

SZAŁACH, S. Edukacja a kształtowanie kompetencji. MAJCHRZAK, N. and STARIK, A. Podmiotowość w edukacji. Poznań: WSB, 2012.

SZCZEPAŃSKA-WOSZCZYNA, K. and DACKO-PIKIEWICZ, Z. Attitudes of graduates towards the education and the career. Economic studies - whether only a knowledge and abilities. Łódź: FEP, 2007. 
WALCZAK, W. Rola kapitału ludzkiego w procesie rozwijania gospodarki opartej na wiedzy. KOPYCIŃSKA, D. (ed.). Kapitat ludzki jako czynnik przewagi konkurencyjnej. Szczecin: Uniwersytet Szczeciński, 2009.

WAWRZEŃCZYK-KULIK, M. Rozwój kompetencji polskich małych i średnich przed-siębiorstw. Zeszyty Naukowe, Ekonomia, 2010, 2(1/2010). Wyższa Szkoła Ekonomii i Innowacji w Lublinie, pp. 83-107.

WINTERTON, J., PARKER, M., DODD, M., McCRACKEN, M. and HENDERSON, I. Future Skill Needs of Managers. Research Report RR182, Sheffield: Department for Education and Employment, 2000.

WOODRUFFE, C. Competent by any other name. Personnel Management, 1991, September, pp. 30-33. 